\title{
The Role of Metadiscourse Markers in Comprehending Texts of Reading Comprehension Books Published in Iran and Oxford University Press
}

Seyed Jamal Ebrahimi*

English Department, Shadegan Branch, Islamic Azad University, Shadegan, Iran

Corresponding Author: Seyed Jamal Ebrahimi, E-mail: sjeiau@gmail.com

\section{ARTICLE INFO}

Article history

Received: November 28, 2017

Accepted: January 29, 2018

Published: May 01, 2018

Volume: 7 Issue: 3

Advance access: March 2018

Conflicts of interest: None

Funding: None

\begin{abstract}
Coherence is considered as the distinctive feature for a text which is achieved by fulfilling two components including texture as the more important one. Structural and non-structural are the two aspects of texture. The earlier deals with inter-sentence or intra-sentence structures including metadiscourse markers. These markers were investigated in this research. A corpus of reading comprehension texts has been compiled from books Published in Iran for university students and compared with similar books printed in Oxford University press. Following investigating each of the lessons in the corpus and contrasting the results, it was found that the texts in Oxford University press used 50 percent more interactive resources and twice more interactional resources. This led to conclude that the texts in Oxford University Press books seem to be more reader-friendly than those in books Published in Iran. Based on the results of this research, Iranian EAP (English for Academic purposes) books developers are recommended to include more interactive metadiscourse markers and much more interactionals to provide studentsfriendlier books.
\end{abstract}

Key words: Metadiscourse Markers, Reading Texts and Eap

\section{INTRODUCTION}

Until mid-1970s, isolated sentences were considered as the base of assessment therefore cohesion did not receive any importance when texts were investigated. Progressively a text was assumed to be more than mere grammatical sentences lined up one after the other and coherence emerged as a component of a text and followed by some more detailed components (Halliday \& Hasan, 1976). These divisions and subdivisions of coherence led to considering metadiscourse markers as one of the elements of inter-sentence and intra-sentence coherence (Hyland, 2005).

The writing skill has been investigated largely for metadiscourse markers presence as one of the factors leading to reader-friendly texts and its scarcity would lead to being a rather difficult text to comprehend (Crismore, 1993). The absence and presence of metadiscourse markers is more important for non-native speakers in the reading comprehension texts as they are looking for every sign to help them decode the meaning that has been put by the writer in the texts.

Textbooks are the basic inseparable component to academic career of the students and play an unreplaceable role in their experience of language learning specifically undergraduate students (Hyland, 2009:112). Although university textbooks have little been researched, the scarcity of research is felt more when it comes to the rhetorical structures. Metadiscourse can serve a few purposes in students' comprehension whether native or non-native. They can have an assisting role in the processing of the information presented in the texts, they could find out the stance of the writer towards the texts and the information included, and finally they could provide a negotiation of the stance and get engaged with the text (Hyland, 2005:178).

Few research investigated metadiscourse from a pedagogical point of view specifically textbooks at the tertiary level. Some of the findings including Cheng and Steffensen (1996), Shaw and Liu (1998), and Xu (2001) found that there is an improvement in the students' writing skill after a period of instructions about the metadiscourse features showing a lack of instructions persistent among the students.

The readers expect to find their texts signalled with metadiscourse markers in a way that suffice them to understand the intended meaning from the texts easily and explicitly (Hyland, 2005:181). Many students [especially non-native students] have problems finding the written texts to be "interactive" and they think that conversation is the only interactive skill (ibid). Therefore, it is quite important to find out if the texts presented by local authors in Islamic Republic of Iran have the potential to serve the readers' purpose so that they include the necessary and sufficient metadiscourse markers to explicitly help them comprehend the texts.

The growing number of non-native English students that have serious problems in universities to pass their EAP 
exams as well as the growing number of students in graduate and postgraduate levels in Iran that need to receive the latest developments in their fields of studies are the other motives behind this research. Furthermore, reading was become an important skill for Iranian university students when compared with other skills as most of them do not communicate in English but they do read the recent developments in English.

This investigation was conducted to determine the status of meta-texts in reading comprehension books taught in Iranian universities. The aspects looked into were the types of metadiscourse markers in reading comprehension texts of books published in Islamic Republic of Iran and Oxford University Press (OUP).

This research could be able to show if the metadiscourse markers in both texts are enough and the students are not aware of the rhetorical structures. In this case, the students need explicitly directed instructions to raise the students' awareness of rhetorical structures which is referred to as rhetorical conscious raising.

This research is aiming to identify the metadiscourse markers types available in reading comprehension textbooks published in Iran as well as those in the ones published by OUP. Also this research tries to find out if there is any relationship between the metadiscourse markers found in both of them.

To fulfil the above-mentioned research objectives, the following questions have been raised to be answered by the findings of this research:

1. What are the metadiscourse markers types used in the reading comprehension textbooks published in Iran?

2. What are the metadiscourse markers types used in the reading comprehension textbooks published by OUP?

3. Is there any relationship between the metadiscourse markers types used in the reading comprehension textbooks published in Iran and by OUP?

\section{LITERATURE REVIEW}

In SFL, there are three conceptions of meaning including "ideational resources for naturalizing reality, interpersonal resources for negotiating social relations, and textual resources for managing information flow"; these meaning-based orientation are referred to as metafunctions. This trinocular metafunctional approach to language led to a tridimensional meaning interpretations, namely, ideational meaning interpreted based on field knowledge, "enabling participation in domestic, recreational, academic, and professional activities", interpersonal meaning allows "valuing these activities and enacting power and solidarity in relation to shared values', and textual meaning allocates ideational and interpersonal meaning phasing in textures sensitive to mode (Martin, 2009). To Crismore, Markkanen and Steffensen (1993: 40) "Metadiscourse can serve what Halliday calls the textual and interpersonal functions".

Williams (1981) pointed out that whenever an author writes or speaks more than a few words, he usually has to write or speak on two levels: the level of direction and the level of information. Williams (1981) used the term metadiscourse to distinguish this kind of writing about reading (level of direction), from writing or speaking about primary topics (level of information).

Crismore (1982) believes that in order for an author to announce that he is changing the subject or coming to a conclusion, that what he is asserting is more or less reliable, or that his ideas are important, he includes some metadiscourse in most texts. Without metadiscourse, he couldn't define terms or acknowledge a difficult line of thought, or even the existence of an audience. She also mentions that the writer or the speaker is responsible for providing appropriate transition statement when moving from one idea to the next and to place signals in the text regularly so the receiver is able to see how the writer or the speaker intends the text together. These signals are called metadiscourse markers. The receiver of the message will better understand the author's text plan if he knows metadiscourse awareness and strategies of using it, (Crismore \& Farnsworth, 1990).

Harris (1952), Williams (1981), Crismore (1982), Goffman (1981) and Vande Kopple (1985) were the pioneers who started working on metadiscourse. These pioneers started with general definitions of the term. Although their definitions had a few functions, they lacked any precise classifications. They worked on metadiscourse, each making some clarifications, justifications and classifications to deliver the picture so informative and clear that later researchers such as Hyland could take it further and finalise the picture as it has been done in writing skill in what Hyland after successive modifications could present the final and most complete model of metadiscourse in writing in 2005 interpersonal model of metadiscourse.

Harris (1952) was the one who coined the term metadiscourse. To him, metadiscourse is a set of kernels used by scientists. These kernels are units of information which result from simple, active, positive, and declarative sentences used to talk about the main material (Aguilar, 2008). He simply defined the term 'metadiscourse' to text elements which provide the reader with comments about the main information of a text, but they themselves include inessential information Harris, 1952). Harris gave metadiscourse such a minor category in his linguistic Model of information retrieval that he used the word as few as four times in his published work (1952). According to him, every sentence is composed of information kernels which are the transformed version of a kernel sentence and then suggested that these kernels could be divided into a maxim of five sections including and assigned a number for each but he gave metadiscourse section the ' 0 ' category (Harris, 1952).

Although Harris definition was not very precise and comprehensive in terms of metadiscourse definition, it could be considered as the first step that started the long journey of the word 'metadiscourse'. In his definition, Harris mentioned that 'metadiscourse' kernels include words totally different from words found in the chief kernels and said that only "metadiscourse kernels ... talk about the main material" (Beauvais, 1986). So we can say that Harris differentiated and separated metadiscourse from other categories (kernels). He gave category zero to metadiscourse which show his little attention to it 
but at least he started considering metadiscourse as a separate kernel with a category number. Harris linguistic model sorted main kernels from those which are not main kernels but talked about the main kernels (metadiscourse); he gave the first definition and coined the word 'metadiscourse' to mark a metadiscourse era, he also identified introductory clauses as a form of metadiscourse and his definition led to a later definition of metadiscourse as "discourse about discourse". There are also some other critics to Harris' work. His main target was to develop a system on how to extract important information from scientific articles to form their abstracts; his definition was to serve a specific and narrow purpose; he provided only one example of a metadiscourse kernel, "we have found that" and classified it in the zero-section including disparate constituents which suggested the limitation of the term to self-referential sentences.

\section{METHOD}

Hyland (2005) worked on three topics or sections. He presented all the information that he had until that time about basic distinctions and classifications of metadiscourse which is a really comprehensive work until now. He also devoted a section to the discussion of the main applications of metadiscourse and its contribution to our understanding of rhetoric, genre and community. The last section of the book is devoted to metadiscourse usage for teachers and students along with its applications and benefits for writing classes. Hyland's (2005) interpersonal model of metadiscourse is depicted in table 1 .

This model is the most comprehensive model that has been presented so far as it has gone through different modifications, tested and completed against many corpora and finalized.

To analyze the data for the metadiscourse markers types, the following analytical procedures will be taken. First, three reading comprehension texts from each of the twelve textbooks were chosen to make a total of 36 units that make the corpus of this research. The researcher decided to keep the name of the books anonymous for secrecy. Second, after establishing the corpus, the researcher proceeded to identify metadiscourse marker types. To this end, the researcher went through all the 36 units carefully and identified the metadiscourse markers of the corpus. In this step, to mitigate the threat of false identification of metadiscourse markers, three raters were invited to check a sample of 4 units from the corpus. The three raters are three students pursuing their $\mathrm{PhD}$ in Applied Linguistics. The differences in metadiscourse markers identifications were subject to negotiation and discussion to reach an agreement. Fourth, the frequency and occurrence of the metadiscourse markers types were recorded and tabulated and discussed to answer the research questions raised in this research.

\section{RESULT AND DISCUSSION}

In order to answer the first question (What are the metadiscourse marker types used in the reading comprehension textbooks published in Islamic Republic of Iran?), the whole 18 texts were analyzed based on Hyland (2005) model of metadiscourse markers. The raw findings of these texts analysis are presented below in table 2 along with their explanations in great details.

In this sub-corpus, it was found that only two of the interactive resources were available and the other three were absent in this sub-corpus. The findings show that the author is paying attention to the transition from one idea to the other and provide the readers (students) with signals to catch their attention to what he is doing. The author used transition markers in all of the texts of the corpus convincing the researcher to term this marker as obligatory among this sub-corpus. The other interactive marker that was present in all of the texts was code glosses allocating the lecturer used the marker to elaborate on the topics or the sub topics presented in the text.

There were instances from two interactional markers that provide an interaction to involve the reader in the text. It was found that all the texts of this sub-corpus included instances from Boosters and also there are more than one instance in each text. Therefore, it is quite clear that this marker is an Obligatory marker in this sub-corpus. The other marker that was present in this sub-corpus is attitude marker. Although

Table 1. Hyland's (2005) interpersonal model of metadiscourse

\begin{tabular}{lll}
\hline Category & Function & Example \\
\hline Interactive resources & Help to guide the reader through the text & \\
\hline Transitions & Express relations between main clauses & In addition, but, thus, and \\
Frame markers & Refer to discourse acts, sequences or stages & Noted above, see Fig, in section 2 \\
Endophoric markers & Refer to information in other parts of the text & According to X, Z states \\
Evidentials & Refer to information from other texts & Namely, e.g., such as, in other words \\
Code glosses & Elaborate propositional meanings & \\
\hline Interactional resources & Involve the reader in the text & Might, perhaps, possible, about \\
\hline Hedges & Withhold commitment and open dialogue & in fact, definitely, it is clear that \\
Boosters & Emphasize certainty and close dialogue & Unfortunately, I agree, surprisingly \\
Attitude markers & Express writer's attitude to proposition & Consider, note, you can see that \\
Engagement markers & Explicitly build relationship with reader & I, we, my, me, our \\
Self-mentions & Explicit reference to author (s) &
\end{tabular}


Table 2. Metadiscourse markers in reading comprehension textbooks printed in Islamic Republic of Iran

\begin{tabular}{lll}
\hline & Category & Occurrences \\
\hline Interactive resources & Transitions & 84 \\
& Frame markers & Nil \\
& Endophoric markers & Nil \\
& Evidentials & Nil \\
& Code glosses & 17 \\
Total & & 101 \\
Interactional resources & Hedges & Nil \\
& Boosters & 77 \\
& Attitude markers & 16 \\
& Engagement markers & Nil \\
Total & Self-mentions & Nil \\
Grand total & & 83 \\
\hline
\end{tabular}

Table 3. An instance of each metadiscourse marker found present in Books printed in Iran

\begin{tabular}{lll}
\hline $\begin{array}{l}\text { Example } \\
\text { number }\end{array}$ & Category & Instance \\
\hline 1 & Transitions & $\begin{array}{l}\text { There was a great deal of } \\
\text { investigation into the crash, but } \\
\text { the final conclusion... } \\
\text { She didn't have a death wish } \\
\text { "like someone I know. } \\
2\end{array}$ \\
3 & Code glosses & You're just tempting fate \\
4 & Attitude & $\begin{array}{l}\text { In her opinion, ESL students } \\
\text { should try to speak English only. }\end{array}$ \\
\hline
\end{tabular}

Table 4. Metadiscourse markers in reading comprehension textbooks in OUP

\begin{tabular}{lll}
\hline & Category & Occurrences \\
\hline Interactive resources & Transitions & 116 \\
& Frame markers & Nil \\
& Endophoric markers & Nil \\
& Evidentials & Nil \\
& Code glosses & 35 \\
Total & & 151 \\
Interactional & Hedges & 32 \\
resources & Boosters & 46 \\
& Attitude markers & 40 \\
& Engagement markers & 47 \\
Total & Self-mentions & Nil \\
Grand total & & 165 \\
\hline
\end{tabular}

this marker was present in all of the texts and can be categorized as Obligatory, it was found only once in each text. An example from each of the above-mentioned markers is presented below:
Also, it was found that Iranian authors of these textbooks used around 80 percent more interactional resources than interactive resources to signal their texts.

Next, the corpus of textbooks published by OUP analysed to find out instances of the metadiscourse markers used by the authors to signal their texts which replied the second research question (What are the metadiscourse marker types used in the reading comprehension textbooks published by OUP?).

As can be noted in the above-mentioned table, especially in the last one, there were six types of metadiscourse markers used in the texts of reading books printed by OUP; two of which were interactive resources and 4 interactional resources. An instance from each of the above mentioned metadiscourse markers which were found in OUP sub corpus is presented in table 5 .

In answering the last research question, there were some interesting results came out when the findings of the two sub corpora were put against each other.

\section{Transitions}

Although the writers in both of the sub corpora were used transitions as obligatory markers to express the relationship among main clauses, the frequency of its occurrences were totally different among the sub corpora.

Table 6 shows that reading comprehension textbooks printed in OUP uses 38 percent more transitions in their presented texts to keep the main clauses more related to each other. Also by comparing this metadiscourse marker that have been used, it could be found that the texts in OUP use far more variant and less repetitive words or strings of words to relate the main clauses together while the texts in PiI are using less variant words or strings of words and repeat them more.

\section{Code Glosses}

Table 7 makes a clearer picture of the results for comparing code glosses found in both sub corpora and also provide a more detailed data in this regard. It shows that in spite of the fact that this metadiscourse marker has the same status as obligatory and found in the same number of sources or texts, the frequency of occurrence is totally different in the two sub corpora. While OUP books for reading comprehension used 35 markers to signal the elaboration about the topic or sub topic they put forward, the textbooks printed in Iran are using less than 50 percent markers to elaborate about the presented topics or sub topics in their texts.

\section{Hedges}

One of the most salient result emerged from the analysis of the two sub corpora is concerned with the usage of Hedges. In spite of its usage in OUP texts, there was not any trace of it in PiI corpus (table 8). It seems that Hedges are of much importance in books published by OUP while they have the least importance (if any) in reading comprehension textbooks published in Iran. This could be considered as one of the most important and striking results came out of this research. 


\section{Boosters}

Boosters are the next metadiscourse marker that was found in all the texts in both of the sub corpora but with different frequencies (table 9). It was found that books published in Iran used 67 percent more boosters than their cognate OUP textbooks that have been designed for non-native English language learners. It clearly shows that Iranian authors have much willingness to close the dialogue and emphasize their certainty when compared with OUP authors.

\section{Attitude Markers}

In many texts the attitude of the writer could be felt while reading the text specifically when the writers try to signpost it. The authors of both Iranian and OUP books had the willing to express their attitude in their books about most of the texts as it was found that this marker had an obligatory status in both of sub corpora (table 10). This willingness is less in Iranian authors so that we could only pinpoint 16 occurrences out of the corpus while the authors of OUP books were more

Table 5. An instance of each metadiscourse marker found present in Books printed in Iran.

\begin{tabular}{|c|c|c|}
\hline $\begin{array}{l}\text { Example } \\
\text { number }\end{array}$ & Category & Instance \\
\hline 1 & Transitions & $\begin{array}{l}\text { Beckham's team won the } \\
\text { Football Association Youth } \\
\text { Cup in his first season. }\end{array}$ \\
\hline 2 & Code glosses & $\begin{array}{l}\text { He didn't build it for himself. } \\
\text { Instead, he built it for the } \\
\text { people in his country. }\end{array}$ \\
\hline 3 & Hedges & $\begin{array}{l}\text { Roughly } 40 \text { percent of the } \\
\text { people... }\end{array}$ \\
\hline 4 & Boosters & $\begin{array}{l}\text { The highest place in his } \\
\text { country is only } 557 \text { feet... }\end{array}$ \\
\hline 5 & Attitude markers & $\begin{array}{l}\text { Denmark is one of the most } \\
\text { bicycle-friendly... }\end{array}$ \\
\hline 6 & $\begin{array}{l}\text { Engagement } \\
\text { markers }\end{array}$ & $\begin{array}{l}\text { Ladders and stars means that } \\
\text { you will reach your dreams. }\end{array}$ \\
\hline
\end{tabular}

willing to express their attitude through the texts and make it clear for the non-native students. The OUP authors used 2.5 times more attitude markers to signpost their expression of their attitude to the proposition. The contradictory point in the results of this marker is that although OUP books had more frequency of this marker available in their texts but Iranian authors had a better spread over the corpus in a way that Iranian authors had spread their 16 attitude markers over 15 texts while OUP authors had spread that high number of markers on 12 sources or texts.

\section{Engagement Markers}

One of the strategies that the writers use to attract the attention of the reader is to build a relationship with the reader. It was found that the authors in both sub corpora are paying less attention to this strategy but it was also found that Iranian authors are paying the least attention (if any) to this strategy while the authors in OUP are paying a moderate attention to this one (table 11). as can be seen (table 11) only the OUP authors used this marker with high frequency (47 occurrences) which shows how important it is to them. But this high occurrence only occurred in 8 texts out of the 18 which was hardly enough to term this marker as semi-obligatory.

Based on these findings, some conclusions could be inferred so that they could be useful for authors trying to publish books to teach non-native students reading comprehension. The conclusions and the recommendations are presented below in details.

First, it was found that authors in OUP have more tendency to use metadiscourse markers to signpost their texts for the readers in comparison with Iranian authors in PiI. The authors in OUP used 316 metadiscourse markers while PiI authors used 184 metadiscourse markers. Therefore, it could be concluded that there are more signals for the students while reading the texts of OUP so that they can move forward easier through the text and get more information from the text

Second, based on the findings it could be concluded that the number of functions used by OUP textbooks' authors are more than those used by PiI authors not only in number of

Table 6. A comparison of transitions in PiI and OUP

\begin{tabular}{lcccccccc}
\hline Metadiscourse marker & \multicolumn{2}{c}{ Occurrences } & & \multicolumn{2}{c}{ Sources } & & & \multicolumn{2}{c}{ Status } \\
\cline { 2 - 3 } & PiI & OUP & & PiI & OUP & & PiI & OUP \\
\hline Transitions & 84 & 116 & & 18 & 18 & & Obligatory & Obligatory \\
\hline
\end{tabular}

Table 7. A comparison of Code glosses in PiI and OUP

\begin{tabular}{|c|c|c|c|c|c|c|}
\hline \multirow[t]{2}{*}{ Metadiscourse marker } & \multicolumn{2}{|c|}{ Occurrences } & \multicolumn{2}{|c|}{ Sources } & \multicolumn{2}{|c|}{ Status } \\
\hline & PiI & OUP & PiI & OUP & PiI & OUP \\
\hline Code glosses & 17 & 35 & 15 & 15 & Obligatory & Obligatory \\
\hline
\end{tabular}

Table 8. A comparison of Hedges in PiI and OUP

\begin{tabular}{|c|c|c|c|c|c|c|}
\hline \multirow[t]{2}{*}{ Metadiscourse marker } & \multicolumn{2}{|c|}{ Occurrences } & \multicolumn{2}{|c|}{ Sources } & \multicolumn{2}{|c|}{ Status } \\
\hline & PiI & OUP & PiI & OUP & PiI & OUP \\
\hline Hedges & 0 & 32 & 0 & 15 & - & Obligatory \\
\hline
\end{tabular}


Table 9. A comparison of boosters in PiI and OUP

\begin{tabular}{|c|c|c|c|c|c|c|}
\hline \multirow[t]{2}{*}{ Metadiscourse marker } & \multicolumn{2}{|c|}{ Occurrences } & \multicolumn{2}{|c|}{ Sources } & \multicolumn{2}{|c|}{ Status } \\
\hline & PiI & OUP & PiI & OUP & PiI & OUP \\
\hline Boosters & 77 & 46 & 18 & 18 & Obligatory & Obligatory \\
\hline
\end{tabular}

Table 10. A comparison of attitude markers in PiI and OUP

\begin{tabular}{|c|c|c|c|c|c|c|}
\hline \multirow{2}{*}{ Metadiscourse marker } & \multicolumn{2}{|c|}{ Occurrences } & \multicolumn{2}{|c|}{ Sources } & \multicolumn{2}{|c|}{ Status } \\
\hline & PiI & OUP & PiI & OUP & PiI & OUP \\
\hline Attitude markers & 16 & 40 & 15 & 12 & Obligatory & Obligatory \\
\hline
\end{tabular}

Table 11. A comparison of engagement markers in PiI and OUP

\begin{tabular}{lcccccccc}
\hline Metadiscourse marker & \multicolumn{2}{c}{ Occurrences } & & \multicolumn{2}{c}{ Sources } & & & \multicolumn{2}{c}{ Status } \\
\cline { 2 - 3 } & PiI & OUP & & PiI & OUP & & PiI & SUP \\
\hline Engagement markers & 0 & 47 & & 0 & 8 & & - & obligatory \\
\hline
\end{tabular}

Table 12. The results of analysis of the corpus

\begin{tabular}{lccc}
\hline Categories & \multicolumn{2}{c}{ Occurrences } \\
\cline { 2 - 3 } & PiI & OUP \\
\hline Interactive resources & 101 & 151 \\
Interactional resources & 83 & 165 \\
Total & 184 & 316 \\
\hline
\end{tabular}

Table 13. Results of PiI and OUP occurrences across functions

\begin{tabular}{lcc}
\hline \multirow{2}{*}{ Functions } & \multicolumn{2}{c}{ Occurrences } \\
\cline { 2 - 3 } & PiI & OUP \\
\hline Transitions & 84 & 116 \\
Code glosses & 17 & 35 \\
Hedges & 0 & 32 \\
Boosters & 77 & 46 \\
Attitude markers & 16 & 40 \\
Engagement markers & 0 & 47 \\
\hline
\end{tabular}

frequencies but also in the number of functions (table 13). As it is mentioned briefly in chapter four, PiI textbooks include only two interactive and two interactional resources or categories while OUP textbooks include the same two interactive function of Transitions and Code glosses as PiI and share Boosters and Attitude markers but also use two more interactional resources of Hedges and Engagement markers. This more usage of interactional functions show that the authors in OUP would like to leave an open dialogue among their texts and also engage the readers more in their texts.

Third, it is also noted that among the texts of OUP there are not only more occurrences and more functions as it is mentioned earlier in this chapter but also there are a variety of words and strings of words to act as the metadiscourse markers for that specific functions while this phenomenon is less noticed in PiI text books (table 14).
Table 14. Words and strings of words used as metadiscourse markers

\begin{tabular}{ll}
\hline & Transitions \\
\hline PiI & 11different lexical phrases \\
OUP & 19 different lexical phrases \\
\hline
\end{tabular}

Finally, it could be concluded that all of the mentioned census in this and the earlier chapter, the texts presented by OUP are more reader-friendly as they include more metadiscourse markers, more variety of them, more number of functions of them. Also, the authors in OUP put their texts with more guidance and assistance for the non-native readers and involve the readers more in their texts.

It could be recommended that further research is done in this regard as the budget of this research was not big enough to include further investigation. Also this research could be done comparing newspapers and magazines printed in two or more different contexts and check their reader-friendliness.

The results of this research are of special benefit to non-native learners textbooks writers as well as to students themselves and their teachers who deal with such kinds of books directly. Furthermore, this research is of much interest for Islamic Azad University lecturers, students and syllabus designers so that they would know what is preferred to be included in the syllabi and the textbooks.

As a final note I would like to express my thanks to Islamic Azad University, Shadegan branch for providing me with this opportunity and the finance needed to do my research in my area of interest.

\section{REFERENCES}

Aguilar, M. (2008). Metadiscourse in academic speech: a relevance-theoretic approach (Vol. 317): Peter Lang Pub Inc. Beauvais, P. J. (1986). Metadiscourse in Context: A Speech Act Model of Illocutionary Content.

Crismore, A. (1982). The Metadiscourse Component: Understanding Writing about Reading Directives. 
Crismore, A., \& Farnsworth, R. (1990). Metadiscourse in popular and professional science discourse.

Crismore, A, Markannen, R, Steffensen, M, (1993). Metadiscourse in Persuasive Writing. A study of texts written by American and Finnish University students. Written Communication, 10(1), 39-71.

Dahl, T, (2004). Textual metadiscourse in research articles: a marker of national culture or of academic discipline? Journal of Pragmatics, 36(10), 1807-1825.

Goffman, E. (1981). Forms of talk: Univ of Pennsylvania Pr.

Harris, Z. S. (1959). Computable syntactic analysis. Transformations and Discourse Analysis Project (TDAP), 15.

Halliday, M. K, and Hasan, R. (1976). Cohesion in English. London: Longman.

Halliday, M. A. K. (1978). Language as social semiotic (p. 136). Arnold: London.

Hyland, K. (2004). Disciplinary discourses: Social interactions in academic writing. University of Michigan Press.

Hyland, K. (2005). Metadiscourse: Exploring interaction in writing: Continuum Intl Pub Group.
Marandi, S. (2003). Metadiscourse in Persian/English master's theses: A contrastive study.

Myers, G, (1989). The pragmatics of politeness in scientific articles. Applied Linguistics, 10(1), 1-35.

Pérez-Llantada, C. (2003). Communication skills in academic monologue discourse. Empirical and applied perspectives. Circulo de Lingüistica Aplicada a la Comunicación, (15), Not-availabe.

Salager-Meyer, F, (1994). Hedges and textual communicative function in medical English written discourse.English for Specific Purposes 13 (2), 149-17

Zarei, G. R., \& Mansoori, S. (2007). Metadiscourse in academic prose: A contrastive analysis of English and Persian research articles. The Asian ESP Journal, 3(2), 24-40.

Vande Kopple, W, (1985). Some exploratory discourse on metadiscourse. College Composition and Communication, 36, 82-93

Williams, Joseph M., (1981). Style: Ten Lessons in Clarity and Grace. Harper Collins Publisher 